\title{
Investigating the Presence of Biotic Agents Associated with Mundulla Yellows
}

Joanne E. Luck, Molecular Plant Pathologist, Rosa Crnov, Virologist, and Barbara Czerniakowski, Soil Scientist, Department of Primary Industries, Primary Industries Research Victoria, Plant Health PMB 15 Ferntree Gully Delivery Centre, 3156 Victoria, Australia; Ian W. Smith, Forest Pathologist, School of Forest and Ecosystem Science, University of Melbourne, Department of Sustainability and Environment, Heidelberg, 3084 Victoria, Australia; and Jane R. Moran, Research Director, Department of Primary Industries, Primary Industries Research Victoria, Australia

\begin{abstract}
Luck, J. E., Crnov, R., Czerniakowski, B., Smith, I. W., and Moran, J. R. 2006. Investigating the presence of biotic agents associated with Mundulla Yellows. Plant Dis. 90:404-410.

The role of biotic agents in the dieback syndrome Mundulla Yellows (MY) was investigated by analysis of 40 Eucalyptus camaldulensis, E. leucoxylon, or E. cladocalyx trees and soil samples from South Australia and Victoria, Australia. No pathogenic fungi, bacteria, phytoplasmas, or insect pests or vectors were found to be associated with MY. However, nematode analysis identified Merlinius spp. to be associated with soil, but not roots, from symptomatic trees. Interveinal chlorosis symptoms were not transmissible by seed, mechanical inoculation, or grafting using plant material derived from symptomatic trees. Virus-like particles were detected at a single symptomatic study site using transmission electron microscopy. MY symptoms were induced in E. camaldulensis seedlings by sowing seed from asymptomatic trees into sterilized and unsterilized soil collected from underneath symptomatic trees. Significantly, sterilized soil induced more severe symptoms in seedlings than unsterilized soil. Soil collected from under asymptomatic trees did not induce MY symptoms. This preliminary investigation indicates that, with the exception of Merlinius spp., pathogenic organisms and pests were not consistently associated with MY symptoms.
\end{abstract}

Mundulla Yellows (MY) is a progressive dieback syndrome of Eucalyptus and other native species, first reported in the 1970s in Eucalyptus camaldulensis. It first was observed near Mundulla, South Australia (SA) (9) but has been reported as occurring in most states of Australia and, more recently, in Spain (8).

The first symptom of MY is leaf interveinal chlorosis, which can occur on trees of any age (Fig. 1A). Yellowing is observed initially in immature leaves on a single branch and spreads to mature leaves, leading to defoliation (Fig. 1B). Any resulting epicormic growth is stunted and chlorotic. MY symptoms gradually spread throughout the tree, causing the whole canopy to die back over several years or decades (Fig. 1C), resulting in tree death.

The symptoms predominantly occur in disturbed vegetation, particularly near roadsides and paths. At least 87 species and 29 genera have been documented as expressing MY-like symptoms in South Australia (17).

Recently, Hanold and Randles observed transmission of MY symptoms in grafting experiments and hypothesized that MY is

Corresponding author: J. E. Luck

E-mail: jo.luck@dpi.vic.gov.au

Accepted for publication 23 September 2005.

DOI: 10.1094/PD-90-0404

(C) 2006 The American Phytopathological Society likely to be associated with a contagious, biotic agent (9). RNA species (200 to 600 nucleotides) of unknown identity were detected in MY-affected Eucalyptus spp. in Australia (7) and in Southern Spain and on the island of Ibiza, Spain (8). However, the RNA also was found in a proportion of healthy trees (7). It was hypothesized that asymptomatic trees containing the MYassociated RNA may have been latently infected with an RNA-based pathogen.

Because of the proximity to roads, pathways, and disturbed vegetation, it also has been hypothesized that root-adsorbed herbicides, such as atrazine and simazine, may contribute to MY symptoms (15).

Despite being observed in Australia for at least 30 years, the cause of MY has not been determined. The following study represents a systematic analysis and com- parison of symptomatic and asymptomatic trees for the presence and association of a biotic agent or agents in the development of MY symptoms. A separate article will address the role of abiotic factors in MY.

\section{MATERIALS AND METHODS}

Study sites. Ten study sites (approximately 150 by $100 \mathrm{~m}$ ) were selected in Mundulla, South Australia and Lara, Victoria, Australia. Five sites contained trees that were affected with typical MY symptoms and five sites contained trees where MY symptoms could not be found. All sites were geographically separated from each other by at least $2 \mathrm{~km}$. All sites contained trees of (predominantly) a single Eucalyptus spp., either E. camaldulensis, E. leucoxylon, or E. cladocalyx (Table 1). Two additional sites were used to collect seed from MY-affected E. arenacea and Corymbia ficifolia for seed transmission experiments (Table 1). Four trees from each of the 10 study sites were selected for investigation. The trees ranged in height and chest height diameter from 3 to $38 \mathrm{~m}$ and 8 to $185 \mathrm{~cm}$, respectively. Each tree was tested for the presence of fungi, nematodes, bacteria, phytoplasma, viruses, and viroids. Insects were collected from tree foliage and understory vegetation to investigate the presence of pests and disease vectors at each site. To determine the possible cause of MY, the results of biotic testing were compared between the 20 symptomatic and 20 asymptomatic trees selected for this study.

Graft transmission. Branch pieces (approximately $1 \mathrm{~cm}$ in diameter) were collected from asymptomatic and symptomatic E. camaldulensis at Victorian and

Table 1. Study sites selected in Victoria (Vic) and South Australia (SA), Australia, investigating the cause of Mundulla Yellows (MY)

\begin{tabular}{lcll}
\hline MY symptoms & Site no. & \multicolumn{1}{c}{ Site name and location } & \multicolumn{1}{c}{ Species } \\
\hline Symptomatic & 3 & Carew, SA & Eucalyptus leucoxylon \\
Symptomatic & 4 & Buckingham Road, Mundulla, SA & E. camaldulensis \\
Symptomatic & 5 & Lara Lake Wetlands, Vic & E. leucoxylon \\
Symptomatic & 6 & Chirnside Park, Vic & E. leucoxylon \\
Symptomatic & 8 & West Geelong, Vic & E. cladocalyx \\
Symptomatic & 11 & Desert Camp Conservation Park, SA & E. arenacea \\
Symptomatic & 12 & Geelong, Vic & Corymbiaficifolia \\
Asymptomatic & 1 & Lowe's, Mundulla, SA & E. leucoxylon \\
Asymptomatic & 2 & Poocher Swamp, Mundulla, SA & E. camaldulensis \\
Asymptomatic & 9 & You Yangs Regional Park, Vic & E. camaldulensis \\
Asymptomatic & 10 & Anakie, Vic & E. leucoxylon \\
Asymptomatic & 7 & Main St., Lara, Vic & E. cladocalyx \\
\hline
\end{tabular}


South Australian study sites (Victoria: October and December 2003 and March 2004; SA: November 2004). All leaves were removed from $10-\mathrm{cm}$-long scions and then grafted using either a "tongue-and-groove" method (17 scions, Victorian samples) or "whip-graft" method (12 scions, South Australian samples) onto 12-month-old unaffected E. camaldulensis rootstock using the
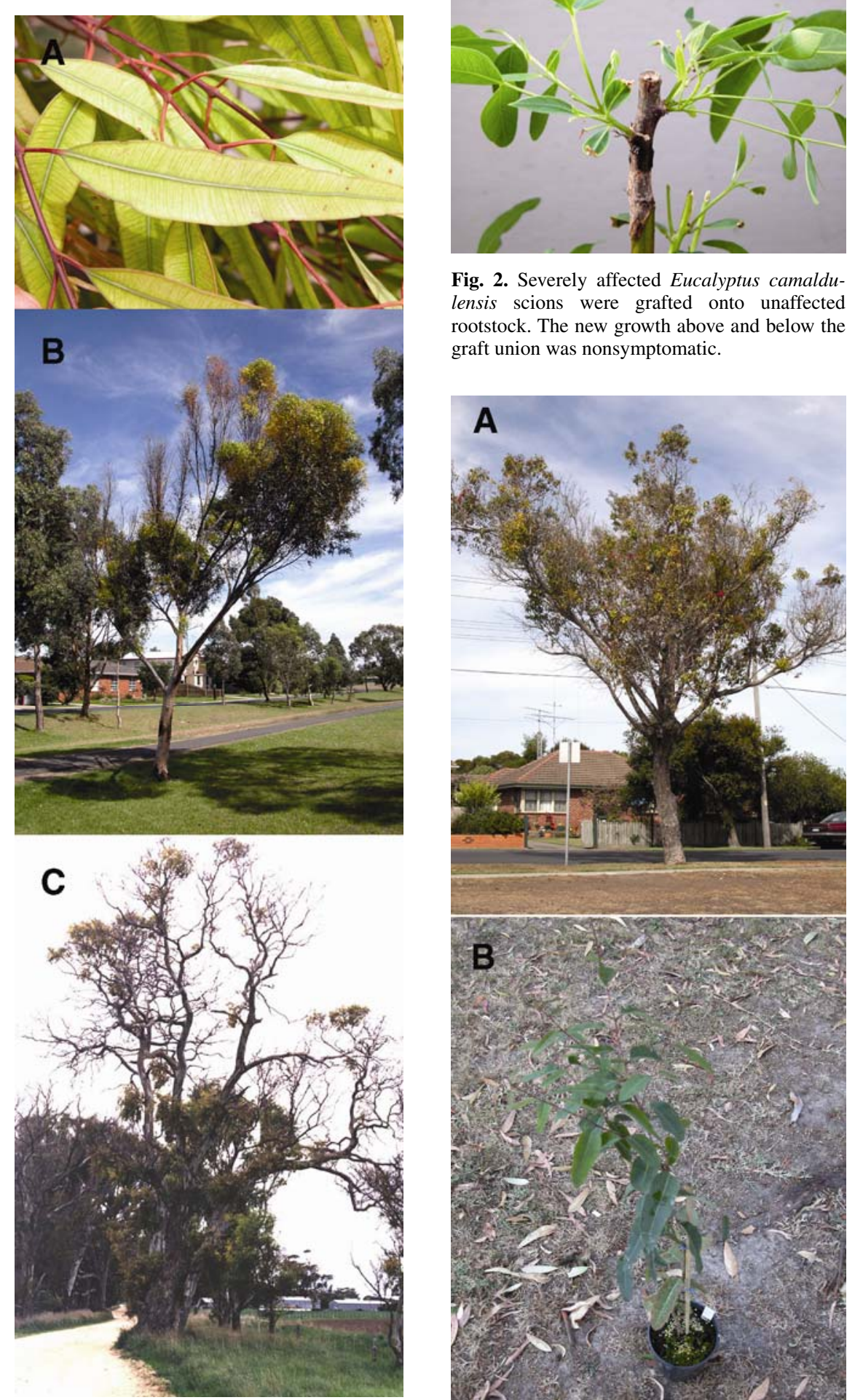

Fig. 1. A, Close-up of interveinal chlorosis in Eucalyptus camaldulensis foliage, Mundulla, South Australia. B, Mundulla Yellows (MY)affected E. camaldulensis, Lara, Victoria, C, Advanced MY symptoms on E. camaldulensis, Mundulla, South Australia.
Fig. 2. Severely affected Eucalyptus camaldulensis scions were grafted onto unaffected rootstock. The new growth above and below the graft union was nonsymptomatic.

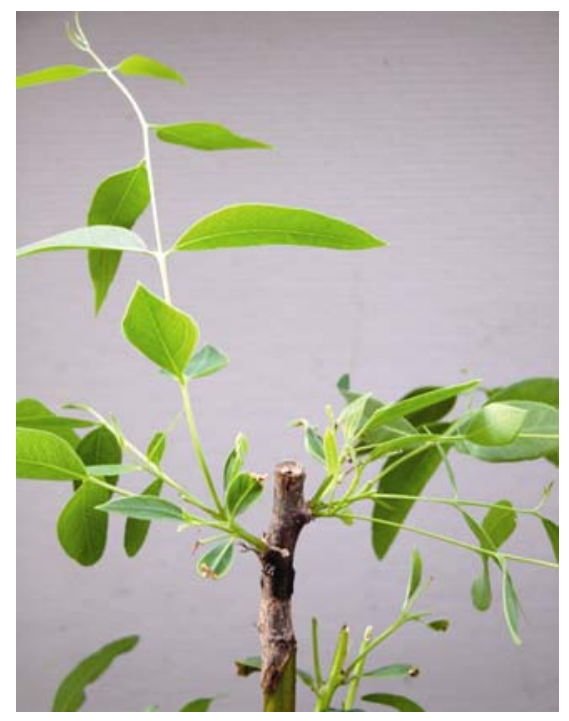

method of Toogood (23). Grafted plants were grown in $\mathrm{Nu}$-Erth regular grade potting mix containing composted organic material, sand, and all the necessary trace elements required for healthy plant establishment conforming to the Australian Standard for potting mixes (AS 3743-1996).

All grafted trees were maintained in the glasshouse at temperatures between 15 and $25^{\circ} \mathrm{C}$ and fertilized every 6 months with a slow-release fertilizer ( $5 \mathrm{~g}$ of OsmocoteOutdoor and Indoor Plant Food).

Seed transmission. Capsules containing seed were collected from severely affected MY C. ficifolia (Geelong, Victoria) and $E$. arenacea (Desert Camp Conservation Park, SA). Capsules were incubated at $25^{\circ} \mathrm{C}$ for 1 week and the resultant released seed was sown into sterilized vermiculite in March 2003 and April 2003, respectively. Seed germinated within 3 weeks of sowing and seedlings were transplanted into $10-\mathrm{cm}$ pots containing sterilized potting mixture and maintained in the glasshouse at 18 to $25^{\circ} \mathrm{C}$. After 2 weeks, the seedlings were fertilized with a slowrelease fertilizer (Osmocote Outdoor and Indoor Plant Food).

Soil sterilization experiments. To investigate the possible presence of soil-
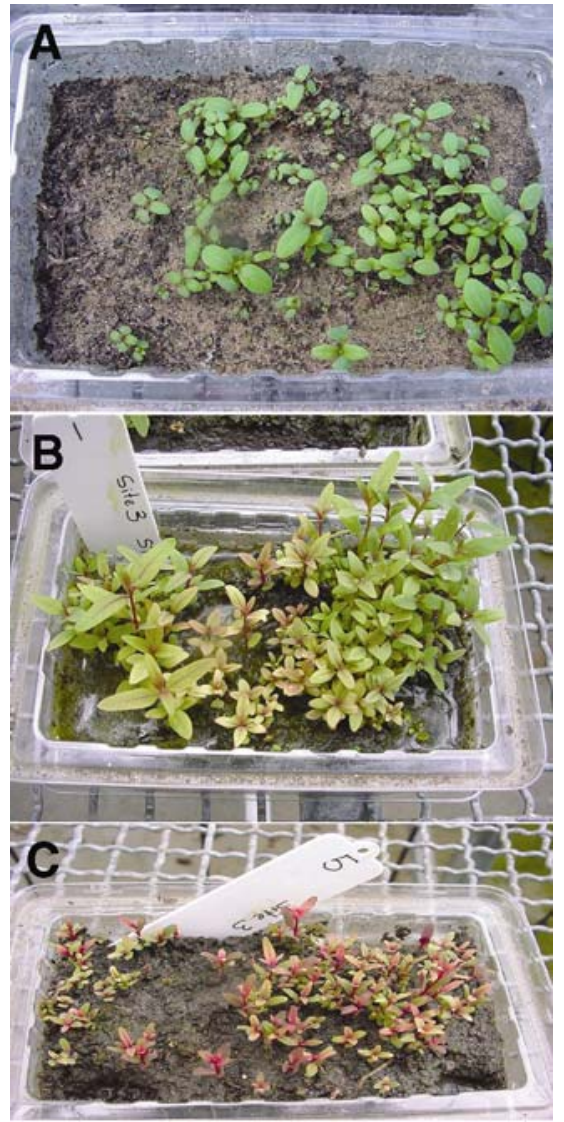

Fig. 4. A, Eucalyptus camaldulensis seed collected from unaffected trees grown in soil from unaffected sites, B, seed collected from unaffected trees grown in unsterilized soil from MY-affected sites, and C, seed collected from unaffected trees grown in sterilized soil from MY-affected sites. 
borne pathogens, E. camaldulensis seed was collected from asymptomatic trees located in Barmah State Forest, Victoria, Australia (MY has not been reported within this state forest). The seed $(0.1 \mathrm{~g})$ was sown into small plastic trays containing $200 \mathrm{~g}$ of sterilized (using a microwave to maintain soil temperature at approximately $80^{\circ} \mathrm{C}$ for $30 \mathrm{~min}$ ) or nonsterilized soil from each of the four South Australian study sites (two symptomatic and two asymptomatic sites). All soil was collected from a depth of 0 to $20 \mathrm{~cm}$. In all, eight sterilized and eight unsterilized replicates were included. The trays were monitored daily and watered approximately twice weekly to maintain soil moisture at field capacity. The seedlings were assessed visually for MY-like symptoms (interveinal chlorosis) and growth rate monitored for 3 months.

Virus and viroid. Herbaceous indexing. Symptomatic and asymptomatic leaves from all trees from all Victorian and South Australian study sites were collected for herbaceous indexing for virus. The leaves were ground in $10 \mathrm{ml}$ of $0.05 \mathrm{M}$, phosphate buffer (1 M K $\mathrm{K}_{2} \mathrm{HPO} 4 / 1 \mathrm{M} \mathrm{KH}_{2} \mathrm{PO} 4$ stock solutions), $\mathrm{pH} 7$, with a mortar and pestle. Herbaceous indicators (Nicotiana tabacum, N. glutinosa, N. rustica, and Chenopodium armaranticolor) were dusted with carborundum powder and rub inoculated with leaf sap in March 2004 (Victorian study sites) and November 2004 (South Australian study sites). All indicators inoculated with Victorian material were monitored for the onset of symptoms for 5 months. Foliage samples collected for herbaceous indexing from South Australian sites were rub inoculated (as per Victorian samples) onto indicators in November 2004.

Transmission electron microscopy. Leaves from all 40 trees across the 10 study sites were collected during spring or summer and were examined for the presence of viruses. Approximately $5 \mathrm{~mm}^{2}$ of leaf tissue was excised and macerated in a drop of sterile distilled water $\left(\mathrm{sdH}_{2} \mathrm{O}\right)$. A carbon-coated formvar grid was placed onto the macerated drop to adsorb sample for $1 \mathrm{~min}$. The grid was inverted and a drop of $2 \%$ aqueous ammonium molybdate was placed directly onto the grid for $30 \mathrm{~s}$. Excess stain was blotted off the grid with a piece of filter paper and the grid left to air dry for $5 \mathrm{~min}$. The grid was examined at $100 \mathrm{kV}$ with a Jeol 200CX transmission electron microscope.

RNA analysis. Total RNA was extracted from tissue of all 40 symptomatic and asymptomatic trees using the modified method of Wan Chow Wah and Symons (25). RNA samples were digested with DNase (Promega Corporation) according to the manufacturer's instructions prior to two-dimensional (2D) reverse polyacrylamide gel electrophoresis (PAGE) (5\% bis:acrylamide, $0.12 \%$ temed, and $0.07 \%$ ammonium persulfate [APS] in $1 \times$ Trisborate EDTA) analysis. Total RNA from pear infected with pear blister canker viroid (PBCVd) was included as a positive control. In addition, RNA also was extracted from healthy pear and used as a negative control. Return-PAGE gels were run and bands were visualized following the method of Singh and Boucher (21).

Fungi. Ten leaves from the 20 symptomatic and 20 asymptomatic trees were removed and washed in $\mathrm{sdH}_{2} \mathrm{O}$. Approximately $40 \mathrm{~g}$ of leaf tissue was excised and ground in $5 \mathrm{ml}$ of $\mathrm{sdH}_{2} \mathrm{O}$. Serial dilutions of sap $(100 \mu \mathrm{l})$ were plated onto potato dextrose agar containing achromycin at $100 \mu \mathrm{g} / \mathrm{ml}(\mathrm{PDA}+\mathrm{A})$ and incubated at $22^{\circ} \mathrm{C}$ for 28 days. Plates were scored for fungal species and numbers of colonies.

A 10 - to $20-\mathrm{cm}$ twig or branch from each tree was sterilized in $70 \%$ ethanol. The branch was split lengthwise and small pieces of heartwood were excised (approximately $10 \mathrm{~cm}$ in length) and incubated on PDA+A for 28 days. Fungal species were identified and their number was recorded. Split branches and leaves were placed in plastic containers on moist tissue paper and incubated at room temperature for 28 days. Samples were monitored weekly and the tissue paper remoistened when necessary.

Five 200-g subsamples of soil (including small root pieces) were collected from a depth of $15 \mathrm{~cm}$ beneath the 20 symptomatic and 20 asymptomatic trees. The samples from each tree were pooled and Phytophthora baiting was conducted using the eucalyptus cotyledon method (14) followed by plating onto $\mathrm{P}_{5} \mathrm{ARPH}$ media (11).

Bacteria. Ten leaves from each of the 20 symptomatic and 20 asymptomatic trees were surface sterilized and excised across the midrib in 1 -by-2- $\mathrm{cm}^{2}$ sections, homogenized gently with a mortar and pestle, and serially diluted using $\mathrm{sdH}_{2} \mathrm{O}$. Aliquots $(100 \mu \mathrm{l})$ of each dilution were plated on to King's B medium (KB) and incubated at $25^{\circ} \mathrm{C}$ for 7 days. Several different colony types from each sample were subcultured and identified using fatty acid methyl analysis (FAME) as described by Weller et al. (27) by New South Wales Agriculture. General biochemical testing was done on each colony type, including gram stains, catalase and oxidase tests, and fluorescence under UV. Polymerase chain reaction (PCR) was used to test for Xylella fastidiosa using the method of Minsavage et al. (16) and Liberobacter asiaticum using the method of Jagoueix et al. (10).

In addition to fatty acid analysis, some colonies were identified using PCR and DNA sequencing. A loopful of pure, 1-dayold culture, growing on $\mathrm{KB}$, was transferred to $200 \mu \mathrm{l}$ of $\mathrm{sdH}_{2} \mathrm{O}$ in a sterile Eppendorf tube. The suspension was homogenized and boiled for $5 \mathrm{~min}$, then chilled on ice for $5 \mathrm{~min}$. An aliquot $(1 \mu \mathrm{l})$ of the boiled suspension was used as template in the PCR reaction. A fragment of 16S rDNA was amplified using the primer pair fD2 and rp1, using the conditions described by Weiseberg et al. (26). The PCR products were purified using the QIAGEN Qiaquick PCR purification kit as per the manufacturer's instructions. Direct DNA sequencing was completed using Big Dye sequencing (BigDye Terminator v3.1, Cycle Sequencing Kits; Applied Biosystems) chemistry by Micromon DNA Sequencing Service (Monash University, Australia).

Phytoplasma. DNA was extracted from $1 \mathrm{~g}$ of leaf midrib from the 20 symptomatic and 20 asymptomatic trees as described previously (13). A DNA extract of tomato tissue containing Tomato Big Bud (TBB) phytoplasma was used as the positive control for PCR reactions. A nested PCR procedure was carried out with two sets of primers; P1 (2) and P7 (19) were used in the first PCR reaction, and fU5 (12) and $\mathrm{m} 23 \mathrm{sr}$ (18) were used in the second reaction. The PCR procedure was described previously (5).

Nematodes. Soil and root material was collected from four points $1 \mathrm{~m}$ from the base of each tree at a depth of 30 to $40 \mathrm{~cm}$. The four samples from each tree were pooled and mixed thoroughly and a subsample of $200 \mathrm{~g}$ was collected. Roots were separated from the soil. Nematodes were extracted from soil using the method of Whitehead and Hemming (28). Nematodes were identified and counted using a dissecting microscope at $\times 20$ or $\times 40$ magnification.

Root material (10 g) was collected from each soil sample and washed to remove soil and debris. Nematodes were extracted from roots based on the method of Fallis (4). Roots were blotted dry on paper towel, weighed, cut into $1-\mathrm{cm}$ pieces, and macerated in $100 \mathrm{ml}$ of water with an electric blender for $5 \mathrm{~s}$ at high speed. The macerate was poured onto tissue paper supported on wire mesh in a tray. Water was added to cover the root pieces, which were incubated at room temperature for 3 days. The root pieces were discarded and the suspension containing nematodes was collected in a beaker and left to settle for $2 \mathrm{~h}$ at room temperature. The supernatant was siphoned off and the nematodes were identified as above.

The Mann-Whitney (nonparametric) test was used to analyze the significance of the nematode numbers (22).

Insects. Sweep netting of understory grasses of large trees and foliage from smaller trees was conducted to investigate the presence of possible vectors of pathogens or insect pests that may be associated with MY symptoms. A yellow sticky trap was deployed in each tree canopy at all sites. At South Australian sites, insects were collected from foliage and branches that were removed with extendable loppers 
or a tree saw. A subsample of the branch was transferred to a plastic bag and kept at $4^{\circ} \mathrm{C}$ until examined. Insects were pinned and identified to at least order or suborder level, with some identified to genus and species levels.

\section{RESULTS}

Graft transmission. Initial attempts at root or scion grafting of 5 asymptomatic and 12 symptomatic E. camaldulensis scions (from Victorian sites) onto asymptomatic E. camaldulensis rootstocks achieved only 5 successful grafts (29\%); 3 from asymptomatic and 2 from symptomatic trees. Repeated grafting experiments of 12 scions from symptomatic trees (from South Australian sites) using a whip-graft technique resulted in 7 successful graft unions $(58 \%)$.

All successful graft unions resulted in healthy new growth. After monitoring for more than 16 months (Victorian samples) and 5 months (South Australian samples), MY symptoms had not developed on either the scions or the rootstocks (Fig. 2). Some general yellowing of foliage was observed in both grafted asymptomatic and symptomatic plants during the growing period which was corrected using Aquasol and Osmocote. Powdery mildew also affected some plants during their growth. The grafted trees will continue to be monitored over the next 3 years to observe any delayed onset of symptoms.

Seed transmission. No MY symptoms developed in any of the C. ficifolia (Fig. $3 \mathrm{~A}$ and $\mathrm{B}$ ) or E. arenacea seedlings over the past 2 years. Although these preliminary results suggest that MY is not transmissible by seed, the trees will be continually monitored to observe any delayed onset of symptoms.

Soil sterilization experiments. Seed collected from healthy $E$. camaldulensis and grown in bulk subsoils from two independent sites with asymptomatic trees emerged as healthy and green seedlings, regardless of whether the soil was sterilized or unsterilized (Fig. 4A). Seed grown in soils from two sites containing sympto- matic trees emerged as chlorotic seedlings with purple or red pigmentation of their vascular tissue (Fig. 4B). Surprisingly, seedlings grown in sterilized soil collected from sites with symptomatic trees had more severe symptoms and stunted growth (Fig. 4C) compared with seedlings grown in unsterilized soils from the same symptomatic sites (Fig. 4B).

Virus and viroid. Herbaceous indexing. Viral symptoms did not develop on any inoculated indicator plants using material from Victorian sites, despite monitoring for 5 months, whereas the positive control, Potato virus $Y$ (PVY), produced typical PVY symptoms within 3 weeks of inoculation. No interveinal chlorosis or virus-like particles were observed in the inoculated indicator samples with transmission electron microscopy (TEM). Sap inoculation with material from SA has resulted in a single indicator plant (N. tabacum) with virus-like symptoms. This plant shows leaf blistering and curling and currently is being grown for subinoculation onto more indicators and further characterization by molecular methods.

TEM. Virus-like particles were detected in 4 of the 40 samples, and all 4 samples were collected from symptomatic $E$. camaldulensis trees at a single study site, at Buckingham Road, SA. Virus-like particles were rigid and ranged in size from approximately $18 \mathrm{~nm}$ in diameter to 191 to $900 \mathrm{~nm}$ in length. Molecular characterization of these particles is in progress. No virus-like particles were detected at any other sites.

RNA analysis. 2D-PAGE analysis of total RNA revealed nucleic acid profiles that were almost identical between all $40 \mathrm{EuCa}$ lyptus spp. samples. Five faint bands were observed per sample, and no bands were found exclusively in symptomatic trees. The bands detected in the Eucalyptus spp. samples were mostly larger than the control band, and none were equivalent in size to the PBCVd control band. A band of 315 nucleotides was detected for the positive control (PBCVd).

Fungi. No known species of pathogenic fungi were found to be associated with MY-symptomatic trees. Many of the fungal colonies could not be identified but there were no colony types consistently associated with symptomatic or asymptomatic tissue. Both symptomatic and asymptomatic samples contained common species of fungi and yeast (Tables 2 to 4). Many unidentified sterile fungi were identified in split branches and leaves from both symptomatic and asymptomatic trees. $M y$ -

Table 3. Fungi isolated from tree heartwood, as part of the investigation into the cause of Mundulla Yellows $^{\mathrm{a}}$

\begin{tabular}{lllllll}
\hline & & \multicolumn{5}{c}{ Fungi identified } \\
\cline { 3 - 6 } Site $^{\mathbf{b}}$ & Symp $^{\mathbf{c}}$ & Eucalyptus spp. & Chaetomium & Phaeoacremonium & Cladosporium & Penicillium \\
\hline 1 & A & leucoxylon & + & - & + & + \\
2 & A & camaldulensis & - & - & - & - \\
7 & A & cladocalyx & - & - & - & - \\
9 & A & camaldulensis & - & - & - & + \\
10 & A & leucoxylon & + & - & - & - \\
3 & S & leucoxylon & - & - & - & + \\
4 & S & camaldulensis & - & - & + & + \\
5 & S & leucoxylon & - & + & - & - \\
6 & S & leucoxylon & + & - & - & - \\
8 & S & cladocalyx & - & - & - \\
\hline
\end{tabular}

${ }^{a}$ Samples were pooled from four trees per site; $+=$ presence and $-=$ absence of fungi.

b Sites are as follows: 1 = Lowe's, $2=$ Poocher Swamp, $3=$ Carew, $4=$ Buckingham Road, $5=$ Lara Lake Wetlands, $6=$ Chirnside Park, $7=$ Main St., Lara, $8=$ West Geelong, $9=$ You Yangs, and $10=$ Anakie.

${ }^{c}$ Asymptomatic (A) or symptomatic (S).

Table 2. Fungi isolated from leaf sap, as part of the investigation into the cause of Mundulla Yellows ${ }^{\mathrm{a}}$

\begin{tabular}{|c|c|c|c|c|c|c|c|c|}
\hline \multirow[b]{2}{*}{ Site $^{\mathrm{b}}$} & \multirow[b]{2}{*}{ Symptoms $^{\mathrm{c}}$} & \multirow[b]{2}{*}{ Eucalyptus spp. } & \multicolumn{6}{|c|}{ Fungi identified } \\
\hline & & & Microsphaeropsis & Cladosporium & Mycosphaerella & Sporothrix & Penicillium & Oidiodendron \\
\hline 1 & A & leucoxylon & + & + & + & - & + & + \\
\hline 2 & A & camaldulensis & + & - & + & + & - & - \\
\hline 7 & A & cladocalyx & + & + & + & - & + & - \\
\hline 9 & A & camaldulensis & + & + & + & - & - & - \\
\hline 10 & A & leucoxylon & + & + & + & + & + & + \\
\hline 3 & $\mathrm{~S}$ & leucoxylon & + & + & + & + & - & - \\
\hline 4 & $\mathrm{~S}$ & camaldulensis & + & + & + & - & - & + \\
\hline 5 & $\mathrm{~S}$ & leucoxylon & + & + & + & + & + & - \\
\hline 6 & $\mathrm{~S}$ & leucoxylon & + & + & + & + & - & - \\
\hline 8 & $\mathrm{~S}$ & cladocalyx & + & + & + & - & - & + \\
\hline
\end{tabular}

a Samples were pooled from four trees per site; $+=$ presence and $-=$ absence of fungi.

${ }^{\mathrm{b}}$ Sites are as follows: 1 = Lowe's, $2=$ Poocher Swamp, 3 = Carew, 4 = Buckingham Road, $5=$ Lara Lake Wetlands, $6=$ Chirnside Park, $7=$ Main St., Lara, 8 $=$ West Geelong, $9=$ You Yangs, and $10=$ Anakie.

c Asymptomatic (A) or symptomatic (S). 
cosphaerella spp. (6) were identified in all leaf sap samples (Table 2). An unidentified Phaeoacremonium spp. (3) was isolated from heartwood from two symptomatic sites only (Table 3). Many unidentified sterile fungi were isolated in split branches and leaves from both asymptomatic and symptomatic trees, as well as the species listed (Table 4). There was no difference in frequency of any of the colony types between asymptomatic and symptomatic trees. No Phytophthora spp. were identified in symptomatic or asymptomatic trees by baiting soils.

Bacteria. No bacterial ooze was observed when pieces of symptomatic leaves were examined under the microscope. In isolations onto $\mathrm{KB}$, there were a higher number of colonies found in trees from asymptomatic sites compared with the symptomatic trees. The most common species isolated were identified by fatty acid analysis as Sphingomonas spp., Flavobacterium spp., and Pseudomonas putida. No known bacterial pathogens were detected except in leaves from trees in one asymptomatic site, where rDNA from one isolate had a $90 \%$ sequence similarity to Curtobacterium flaccumfaciens pv. poinsettiae. Xylella fastidiosa and Liberobacter asiaticum were not detected by PCR in any of the 40 trees examined.

Phytoplasma. Phytoplasmas were not detected in any of the 40 trees. PCR detection for phytoplasmas produced a 1,447-bp band in 4 of 20 asymptomatic trees and in 0 of 20 symptomatic trees. DNA sequencing indicated a high sequence similarity with the 16S rRNA gene from the bacterium Streptococcus spp.

Nematodes. The total number of nematodes present in soil samples $(120,825)$ was greater than in roots $(48,956)$, with Tylenchus spp. (20) being the most ubiquitous nematodes extracted from both symptomatic and asymptomatic sites from soils and roots. (Table 5 and 6). Use of the Mann-Whitney test (22) to determine whether there was any significance in nematode numbers between symptomatic and asymptomatic sites revealed that only Merlinius spp. numbers were significantly higher in soil samples collected from sites having symptomatic trees compared with sites having asymptomatic trees $(P<0.01)$. Merlinius spp. are ectoparasitic (20), accounting for their absence from all root samples (Table 6).
Insects. Insect sampling over two seasons did not identify any pests or vectors that were associated exclusively with symptomatic trees (Table 7). Families of insects that are known to contain vectors of plant pathogens were identified at both symptomatic and asymptomatic sites (e.g., leafhoppers [Cicadellidae], psyllids [Psylloidea], and aphids). The vegetable leafhopper and the Australian grass leafhopper, Nesoclutha pallida, (Deltocephalinae) were identified in understory grass sweeps. Psyllids were identified at all study sites. Aphids were detected in samples at two asymptomatic sites and one symptomatic site. Xylem-feeding spittlebugs were identified at one site in the late spring sampling.

\section{DISCUSSION}

The most revealing outcome of this work relates to the soil sterilization experiments. Healthy E. camaldulensis seed sown in sterilized and unsterilized soils from MY-symptomatic sites produced seedlings with distinctive MY chlorotic symptoms, with the symptoms being more severe in sterilized soils from symptomatic sites. Conversely, planting of healthy $E$.

Table 4. Fungi isolated from leaves and split branches, as part of the investigation into the cause of Mundulla Yellows ${ }^{\mathrm{a}}$

\begin{tabular}{|c|c|c|c|c|c|c|c|c|}
\hline \multirow[b]{2}{*}{ Site $^{b}$} & \multirow[b]{2}{*}{ Symptoms ${ }^{c}$} & \multirow[b]{2}{*}{ Eucalyptus spp. } & \multicolumn{3}{|c|}{ Fungi identified from leaves } & \multicolumn{3}{|c|}{ Fungi identified from split branches } \\
\hline & & & Trichoderma & Cladosporium & Penicillium & Trichoderma & Cladosporium & Rhizopus \\
\hline 1 & $\mathrm{~A}$ & leucoxylon & + & + & + & - & - & - \\
\hline 2 & $\mathrm{~A}$ & camaldulensis & + & - & + & - & - & + \\
\hline 7 & $\mathrm{~A}$ & cladocalyx & - & - & - & + & - & - \\
\hline 9 & A & camaldulensis & + & + & - & + & + & - \\
\hline 10 & $\mathrm{~A}$ & leucoxylon & + & - & + & - & - & - \\
\hline 3 & $\mathrm{~S}$ & leucoxylon & - & - & - & - & - & - \\
\hline 4 & $\mathrm{~S}$ & camaldulensis & + & - & - & - & - & - \\
\hline 5 & $\mathrm{~S}$ & leucoxylon & - & - & - & + & - & + \\
\hline 6 & $\mathrm{~S}$ & leucoxylon & - & + & - & - & - & - \\
\hline 8 & $\mathrm{~S}$ & cladocalyx & - & - & - & - & - & + \\
\hline
\end{tabular}

a Samples were pooled from four trees per site; $+=$ presence and $-=$ absence of fungi.

b Sites are as follows: 1 = Lowe's, $2=$ Poocher Swamp, 3 = Carew, 4 = Buckingham Road, $5=$ Lara Lake Wetlands, $6=$ Chirnside Park, $7=$ Main St., Lara, 8 $=$ West Geelong, $9=$ You Yangs, and $10=$ Anakie.

${ }^{\mathrm{c}}$ Asymptomatic (A) or symptomatic (S).

Table 5. Nematode species and numbers identified from soils, as part of the investigation into the cause of Mundulla Yellows ${ }^{\mathrm{a}}$

\begin{tabular}{|c|c|c|c|c|c|c|c|c|c|c|c|c|c|c|}
\hline Site $^{b}$ & Symp $^{c}$ & $\begin{array}{c}\text { Eucalyptus } \\
\text { spp. }\end{array}$ & Praty & Ty & Hemi & Moru & Paraty & Het & Hemicr & Paratric & Helico & Paralo & Mer & Total no. \\
\hline 1 & A & leucoxylon & 396 & 672 & 12 & 84 & 396 & 108 & 0 & 0 & 0 & 0 & 0 & 1,668 \\
\hline 2 & A & camaldulensis & 0 & 2,658 & 0 & 1,080 & 361 & 0 & 156 & 48 & 0 & 0 & 0 & 4,303 \\
\hline 7 & A & cladocalyx & 6 & 174 & 0 & 0 & 400 & 0 & 0 & 0 & 0 & 0 & 6 & 586 \\
\hline 9 & A & camaldulensis & 0 & 54,378 & 0 & 0 & 1,944 & 0 & 0 & 0 & 0 & 6 & 0 & 56,328 \\
\hline 10 & A & leucoxylon & 0 & 240 & 666 & 0 & 6 & 0 & 0 & 0 & 0 & 0 & 0 & 912 \\
\hline 3 & $\mathrm{~S}$ & leucoxylon & 6 & 2,497 & 0 & 0 & 618 & 0 & 12 & 0 & 30 & 6 & 231 & 3,400 \\
\hline 4 & $\mathrm{~S}$ & camaldulensis & 132 & 810 & 0 & 18 & 8,358 & 0 & 0 & 0 & 0 & 102 & 84 & 9,504 \\
\hline 5 & $\mathrm{~S}$ & leucoxylon & 222 & 1,458 & 0 & 0 & 102 & 0 & 0 & 0 & 0 & 0 & 78 & 1,860 \\
\hline 6 & S & leucoxylon & 66 & 39,474 & 0 & 0 & 1,122 & 0 & 0 & 0 & 0 & 0 & 72 & 40,734 \\
\hline 8 & $\mathrm{~S}$ & cladocalyx & 792 & 312 & 84 & 0 & & 0 & 48 & 0 & 0 & 0 & 246 & 1,482 \\
\hline$P$ value & $\ldots$ & $\ldots$ & 0.10 & 0.69 & 0.72 & 0.44 & 0.84 & & 1.00 & & & 0.72 & 0.01 & $\ldots$ \\
\hline Total no. & $\ldots$ & $\ldots$ & 1,620 & 102,673 & 762 & 1,182 & 13,307 & 108 & 216 & 48 & 30 & 114 & 717 & $\ldots$ \\
\hline
\end{tabular}

a Nematode abbreviations are as follows: Ty (Tylenchus spp.), Hemi (Hemicylophora spp.), Moru (Morulamius spp.), Paraty (Paratylenchus spp.), Het (Heterodera spp.), Hemicr (Hemicriconemoides spp.) Paratric (Paratrichodorus spp.), Paralo (Paralongidorus spp.), Mer (Merlinius spp.), and Helico (Helicotylenchus spp.).

${ }^{\text {b }}$ Sites are as follows: 1 =Lowe's, $2=$ Poocher Swamp, 3 = Carew, 4 = Buckingham Road, $5=$ Lara Lake Wetlands, $6=$ Chirnside Park, $7=$ Main St., Lara, 8 $=$ West Geelong, $9=$ You Yangs, and $10=$ Anakie.

c Asymptomatic (A) or symptomatic (S). 
camaldulensis seedlings into sterilized and unsterilized soils from asymptomatic sites did not produce MY symptoms. All resulting leaves were asymptomatic. These findings suggest that soil abiotic factors contribute to the development of MY symptoms. The heating of symptomatic soils during the sterilization process markedly increased the severity of symptoms in seedlings. To explain this phenomenon and to identify which abiotic factors are involved in MY symptom development, extensive sampling of soil and foliage from symptomatic and asymptomatic trees has been undertaken and will be published elsewhere (B. Czerniakowski, R. Crnov, I. W. Smith, and J. E. Luck, unpublished).
No bacterial pathogens were associated with MY-affected trees and, in this study, no phytoplasmas were detected in either asymptomatic or symptomatic trees. In other studies, phytoplasmas have been identified in Eucalyptus spp. but no correlation was found with MY symptoms (5). Fungal analysis did not detect any known fungal pathogens exclusively associated with MYaffected trees. No known insect pests or vectors of plant pathogens were identified as being associated with MY-affected trees. No biotic agent was transmitted in grafting experiments, onto herbaceous indicators, or through seed. The grafting data reported here does not support the hypothesis that MY is a graft-transmissible agent (9).
Virus-like particles were detected at one South Australian symptomatic study site, using TEM. The absence of these particles in symptomatic trees from all other sites suggests that it is unlikely that a virus is the causal agent of MY. A possible scenario is that the yellow leaves on trees at this site (symptomatic of MY) may have attracted insects vectoring a virus. The virus may be contributing to MY tree symptoms or may be cryptic within the host. Grafting experiments and herbaceous indexing experiments of these virus-like particles onto indicators, using material from this single site, has not produced interveinal chlorosis in foliage. Experiments are in progress to identify the virus-

Table 6. Nematode species and numbers identified from roots, as part of the investigation into the cause of Mundulla Yellows ${ }^{\mathrm{a}}$

\begin{tabular}{|c|c|c|c|c|c|c|c|c|c|c|c|c|c|c|}
\hline Site ${ }^{\mathbf{b}}$ & Symp & $\begin{array}{c}\text { Eucalyptus } \\
\text { spp. }\end{array}$ & Praty & Ty & Hemi & Moru & Paraty & Het & Hemicr & Paratric & Helico & Paralo & Mer & Total no. \\
\hline 1 & A & leucoxylon & 0 & 341 & 0 & 0 & 0 & 2,803 & 0 & 0 & 0 & 0 & 0 & 3,144 \\
\hline 2 & A & camaldulensis & 0 & 3,075 & 0 & 0 & 58 & 0 & 0 & 0 & 0 & 0 & 0 & 3,144 \\
\hline 7 & A & cladocalyx & 0 & 0 & 0 & 0 & 0 & 0 & 0 & 0 & 0 & 0 & 0 & 0 \\
\hline 9 & A & camaldulensis & 0 & 23,302 & 0 & 0 & 81 & 0 & 0 & 0 & 0 & 0 & 0 & 23,383 \\
\hline 10 & A & leucoxylon & 0 & 328 & 0 & 0 & 0 & 0 & 0 & 0 & 0 & 0 & 0 & 328 \\
\hline 3 & $\mathrm{~S}$ & leucoxylon & 212 & 183 & 0 & 0 & 0 & 0 & 0 & 0 & 0 & 0 & 0 & 395 \\
\hline 4 & $\mathrm{~S}$ & camaldulensis & 6,959 & 373 & 0 & 0 & 98 & 0 & 0 & 0 & 0 & 0 & 0 & 7,430 \\
\hline 5 & $\mathrm{~S}$ & leucoxylon & 10,571 & 0 & 0 & 0 & 0 & 0 & 0 & 0 & 0 & 0 & 0 & 10,571 \\
\hline 6 & $\mathrm{~S}$ & leucoxylon & 0 & 517 & 0 & 0 & 0 & 0 & 0 & 0 & 0 & 0 & 0 & 517 \\
\hline 8 & $\mathrm{~S}$ & cladocalyx & 0 & 49 & 0 & 0 & 0 & 0 & 0 & 0 & 6 & 0 & 0 & 55 \\
\hline$P$ value & $\ldots$ & $\ldots$ & 0.17 & 0.46 & $\ldots$ & $\ldots$ & 1.00 & & $\ldots$ & $\ldots$ & $\ldots$ & $\ldots$ & $\ldots$ & $\ldots$ \\
\hline Total no. & $\ldots$ & $\ldots$ & 17,742 & 28,168 & 0 & 0 & 237 & 2,803 & 0 & 0 & 6 & 0 & 0 & $\ldots$ \\
\hline
\end{tabular}

${ }^{a}$ Nematode abbreviations are as follows: Ty (Tylenchus spp.), Hemi (Hemicylophora spp.), Moru (Morulamius spp.), Paraty (Paratylenchus spp.), Het (Heterodera spp.), Hemicr (Hemicriconemoides spp.) Paratric (Paratrichodorus spp.), Paralo (Paralongidorus spp.), Mer (Merlinius spp.) and Helico (Helicotylenchus spp.).

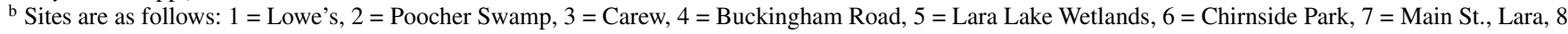
$=$ West Geelong, $9=$ You Yangs, and $10=$ Anakie.

${ }^{c}$ Asymptomatic (A) or symptomatic (S).

Table 7. Examples of insects collected during spring 2004 from South Australian symptomatic and asymptomatic sites, as part of the investigation into the cause of Mundulla Yellows

\begin{tabular}{|c|c|c|c|}
\hline Site, class (if not Insecta), order or suborder & Superfamily or family & Species name & Common name \\
\hline \multicolumn{4}{|l|}{ Buckingham Road, symptomatic } \\
\hline Diptera & Undetermined & Undetermined & Flies \\
\hline Hemiptera; Heteroptera & Tingidae & Undetermined & Lace bugs \\
\hline Hemiptera; Homoptera & Cicadellidae; Typhlocybinae & Zygina zealandica & Leafhoppers \\
\hline Hemiptera; Homoptera & Cicadellidae; Deltocephalinae & Arawa spp., Balclutha spp. & Leafhoppers \\
\hline Hemiptera; Homoptera & Delphacidae & Toya spp. & Delphacid planthoppers \\
\hline Hemiptera; Homoptera & Psylloidea & Undetermined & Psyllids \\
\hline Hymenoptera & Undetermined & Undetermined & Wasps \\
\hline Hymenoptera & Formicidae; Dolichoderinae & Iridomyrmex spp. & (Meat ants) \\
\hline Psocoptera & Undetermined & Undetermined & Booklice/psocids \\
\hline Thysanoptera & Undetermined & Undetermined & Thrips \\
\hline \multicolumn{4}{|l|}{ Lowe's, asymptomatic } \\
\hline Arachnida; Acarina & Undetermined & Undetermined & Mites \\
\hline Arachnida; Araneae & Undetermined & Undetermined & Spiders \\
\hline Coleoptera & Lathriididae & Undetermined & (Minute mould beetles) \\
\hline Coleoptera & (other families) & Undetermined & Beetles \\
\hline Diptera; Nematocera & Undetermined & Undetermined & Flies \\
\hline Diptera; Brachycera & Undetermined & Undetermined & Flies \\
\hline Hemiptera; Heteroptera & Miridae & Undetermined & Mirid bugs \\
\hline Hemiptera; Homoptera & Aphididae & Undetermined & Aphids \\
\hline Hemiptera; Homoptera & Cicadellidae; Typhlocybinae & Zygina zealandica & Leafhoppers \\
\hline Hemiptera; Homoptera & Cicadellidae; Deltocephalinae & Arawa spp., Nesoclutha pallida & Leafhoppers \\
\hline Hemiptera; Homoptera & Cicadellidae; Ulopinae; Cephalelinae & Cephalelini spp. & Seed-mimicking leafhoppers \\
\hline Hemiptera; Homoptera & Psylloidea & Undetermined & Psyllids \\
\hline Hymenoptera & Undetermined & Undetermined & Wasps \\
\hline Hymenoptera & Formicidae; Dolichoderinae & Iridomyrmex spp. & (Meat ants) \\
\hline Hymenoptera & Formicidae; Dolichoderinae & Ochetellus spp. & Spinifex ant \\
\hline Hymenoptera & Formicidae; Myrmicinae & Podomyrma spp. & Muscleman tree-ants \\
\hline Orthoptera & Undetermined & Undetermined & Grasshoppers \\
\hline
\end{tabular}


like particles. The complete data set, including TEM photos of particles, will be reported subsequently. Spherical virus-like particles were isolated from diseased $E$. macrorhyncha by Brzostowski and Grace in 1974, but particles were never purified or characterized (1).

Multiple faint RNA bands were identified in both symptomatic and asymptomatic trees using 2-D reverse PAGE analysis for the detection of viroids. Importantly, no bands were associated exclusively with symptomatic trees. The full characterization of the multiple RNA bands will determine whether the RNA is associated with a pathogen or is derived from the host. Triki et. al. (24) reported the role of Mn deficiency in a yellowing disorder of date palms and described the association of a double-stranded RNA with symptomatic trees. Its subsequent characterization revealed that the RNA was chloroplast derived and not a pathogenic agent. To address the possibility of asymptomatic trees being latently infected with a virus or "virus-like" agent, sampling methods specifically included the geographical separation of asymptomatic sites from symptomatic sites. Grafting, inoculation, and TEM results do not support the association of a virus-like organism with MY symptoms.

The association of Merlinius spp. with symptomatic trees is interesting. It is not known what role this nematode, commonly referred to as the stunt nematode, has in MY etiology. There is little data available on the pathogenicity of this organism, particularly in association with eucalypts (20). A primary pathogenic role is unlikely, given that typical MY symptoms were induced with sterilized soil. It is more likely that Merlinius spp. play a secondary role in symptom development or that they are associated with grasses surrounding the trees. Inoculation studies will determine whether the presence of Merlinius spp. contributes to MY symptoms.

This study did not demonstrate the involvement of pests or pathogens in the etiology of MY. Data indicating that soil factors play a role in the development of MY symptoms will be presented in a subsequent article (B. Czerniakowski, R. Crnov, I. W. Smith, and J. E. Luck, unpublished).

\section{ACKNOWLEDGMENTS}

We thank S. Williams, the South Australian Department for Environment and Heritage; I. Pascoe,
L. Semeraro, F. Constable, J. Wainer, and L. Nambiar, Department of Primary Industries Victoria; D. Cheal and S. Smith, Department of Sustainability and Environment Victoria; D. Smith and P. Clements, School of Forest and Ecosystem Science, University of Melbourne; I. Rogers, City of Greater Geelong and contract staff; staff of Parks Victoria, You Yangs Regional Park; G. Jaudzems, Monash University; G. Cotton, apiarist, South Australia; G. Hinge and A. Lowe, property owners near Mundulla; D. Paton, Adelaide University; K. Robb, University of California-Davis; D. Noble and R. Cother, New South Wales Agriculture; the South Australian Department for Environment and Heritage; and the Australian Department of the Environment and Heritage for supporting our research into Mundulla Yellows.

\section{LITERATURE CITED}

1. Brzostowski, H. W., and Grace, T. D. C. 1974. Virus-like particles isolated from diseased eucalypts. Plant Dis. Rep. 58(1):92-93.

2. Deng, S., and Hiruki, C. 1991. J. Microbiol. Methods 14:53-61

3. Ellis, M. B. 1971. Dematiaceous Hyphomycetes. CAB Press, Commonwealth Agricultural Bureau, Surrey, England.

4. Fallis, A. M. 1943. Use of the Waring blender to separate small parasites from tissue. Can. J. Public Health 34:44.

5. Gibb, K., Mowles, A., and Randles, J. 2000. Mundulla Yellows phytoplasma research. A report into the association between Mundulla Yellows disease of Eucalyptus spp. and phytoplasma infection. Transport South Australia and Environment Australia, Canberra.

6. Hanlin, R. T. 1990. Illustrated Genera of Ascomycetes. American Phytopathological Society, St. Paul, MN.

7. Hanold, D., and Randles, J. W. 2001. An investigation of the cause and impacts of Mundulla Yellows. Final Report to Environment Australia for the Consultancy of January 2000 to May 2001.

8. Hanold, D., and Randles J.W. 2003. First report of Mundulla Yellows on Eucalyptus spp. outside Australia. Plant Dis. 87:875

9. Hanold, D., Stukely, M., and Randles, J. W. 2002. Mundulla Yellows-a new tree-dieback threat. Landscope Mag. (Winter):1-8.

10. Jagoueix, S., Bove, J. S., and Garnier, M. 1997. Comparison of the $16 \mathrm{~S} / 23 \mathrm{~S}$ ribosomal intergenic regions of "Candidatus Liberobacter asiaticum" and "Candidatus Liberobacter africanum", the two species associated with citrus huanglongbing (greening) disease. Int. J. Syst. Bacteriol. 47(1):224-227.

11. Jeffers, S. N., and Martin, S. B. 1986. Comparison of two media selective for Phytophthora and Pythium species. Plant Dis. 70:1034-1043.

12. Lorenz, K.-H., Schneider, B., Ahrens, U., and Seemüller, E. 1995. Detection of the apple proliferation and pear decline phytoplasmas by PCR amplification of ribosomal and nonribosomal DNA. Phytopathology 85:771-776.

13. Maixner, M., Ahrens, U., and Seemuller, E. 1995. Detection of the German grapevine yellows (Vergilbungskrankheit) MLO in grapevine, alternative hosts and a vector by a specific grapevine PCR procedure. Eur. J. Plant
Pathol. 101:241-250.

14. Marks, G. C., and Kassaby, F. Y. 1974. Detection of Phytophthora cinnamomi in soils. Aust. For. 36:198-203.

15. McNamara, J. A. 2003. Mundulla Yellows, a simple case of poisoning. Aust. Biol. 16:94107.

16. Minsavage, G. V., Thompson, C. M., Hopkins, D. L., Leite, R. M. V. B. C., and Stall, R. E. 1994. Development of a polymerase chain reaction protocol for detection of Xylella fastidiosa in plant tissue. Phytopathology 84:456461.

17. Mundulla Yellows Task Group. 2004. A Report on MY in Australia. (NRPPC NRMMC). The Natural Resource Policies and Programs Committee. Natural Resources Management Ministerial Council. Department of Environment and Heritage, Canberra, Australia.

18. Padovan, A. C., Gibb, K. S., Bertaccini, A., Vibio, M., Bonfiglioli, R. E., Magarey, P. A., and Sears, B. B. 1995. Molecular detection of the Australian grapevine yellows phytoplasma and comparison with grapevine yellows phytoplasmas from Italy. Aust. J. Grape Wine Res. $1: 25-31$.

19. Schneider, B., Ahrens, U., Kirkpatrick, B. C., and Seemuller, E. 1993. Classification of plant-pathogenic mycoplasma-like organisms using restriction-site analysis of PCRamplified 16S rDNA J. Gen. Microbiol. 139:519-527.

20. Siddiqi, M. R. 2000. Tylenchida. Parasites of Plants and Insects, 2nd ed. CABI Publishing, St. Albans, UK

21. Singh, R. P., and Boucher, A. 1987. Electrophoretic separation of a severe from mild strains of potato spindle tuber viroid. Phytopathology 77(11):1588-1591.

22. Sokal, R. R., and Rohlf, F. J. 1999. Biometry-The Principles and Practice of Statistics in Biological Research, 3rd ed. W. H. Freeman and Company, New York.

23. Toogood, A. 1999. Propagating Plants. The Royal Horticultural Society, Dorling Kindersley Ltd., London.

24. Triki, M. A., Zouba, A., Khoualdia, O., Ben Mahamoud, O., Takrouni, M. L., Garnier, M. Bové, J. M., Montarone, M., Poupet, A., Flores, R., Darós, J. A., Fadda, Z. G. N., Moreno, P., and Duran-Vila, N. 2003. Maladie des feuilles cassantes or brittle leaf disease of date palms in Tunisia: biotic or abiotic disease? J. Plant Pathol. 85(3):71-79.

25. Wan Chow Wah, Y. F., and Symons, R. H. 1997. A high sensitivity RT-PCR assay for the diagnosis of grapevine viroids in field and tissue culture samples. J. Virol. Methods 63(12):57-69.

26. Weisburg, W. G., Barns, S. M., Pelletier, D. A., and Lane, D. J. 1991. 16S Ribosomal DNA amplification for phylogenetic study. J. Bacteriol. 173(2):697-703.

27. Weller, S. A., Aspin, A., and Stead, D. E. 2000. Classification and identification of plantassociated bacteria by fatty acid profiling. OEPP/EPPO Bull. 30:375-380.

28. Whitehead, A. G., and Hemming, J. R. 1965. A comparison of some quantitative methods of extracting small vermiform nematodes from soil. Ann. Appl. Biol. 55:25-33. 